\title{
A Two-Pronged Standard of Appellate Review for Pretrial Bail Determinations
}

\section{Michael Edmund O'Neill}

The enactment of the Bail Reform Act of 1984 (BRA) ${ }^{1}$ marks a dramatic revision in bail administration. ${ }^{2}$ Prior to the 1984 Act, bail was understood chiefly as a means of guaranteeing the integrity of the judicial system by assuring the defendant's appearance at trial. ${ }^{3}$ The BRA, however, represents a "significant departure" from this traditional philosophy because it authorizes a judicial officer to incarcerate an individual to thwart future crimes. ${ }^{5}$ Expressly authorized pretrial detention based upon a prediction of future dangerousness is unprecedented in this country's history of criminal justice. ${ }^{6}$ Indeed, it defies traditional notions of liberty and justice prior to trial.

Although the BRA contains detailed guidelines judicial officers must follow in order to deny bail, ${ }^{8}$ it provides no statutory standard for appeals courts to review lower court bail determinations. Consequently, a sharp division among the circuits has arisen. Some circuits demand de novo review of trial court decisions, ${ }^{9}$ while others give great deference to lower court rulings and will reverse only if the lower court has committed clear error. ${ }^{10}$ In order to ensure uniform, just review, it is essential to determine

1. Pub. L. No. $98-473,98$ Stat. 1837 (codified at 18 U.S.C. $\$ \S 3141-3150$ (1988)).

2. A number of articles assess the BRA's impact on the criminal justice system. See, e.g., Goldcamp, Danger and Detention: A Second Generation of Bail Reform, 76 J. CRIM. L. \& CRIMINoLOGY 1 (1985) (discussing problems inherent in pretrial detention based on dangerousness); Lay \& $\mathrm{De}$ La Hunt, The Bail Reform Act of 1984: A Discussion, 11 WM. Mrtchell L. Rev. 929 (1985) (discussing revisions in bail made by $1984 \mathrm{Act}$ ).

3. See Stack v. Boyle, 342 U.S. 1, 5 (1951); see also Verrilli, The Eighth Amendment and the Right to Bail: Historical Perspectives, 82 Colum. L. REv. 328, 331 (1982) (original purpose of bail was to preserve judicial integrity).

4. S. Rep. No. 225, 98th Cong., 2d Sess. 3 (1983), reprinted in 1984 U.S. Code Cong. \& ADMIN. NEWS 3182, 3185-86 [hereinafter S. REP.].

5. 18 U.S.C. § 3142(e)(1988); see also S. REP., supra note 4, at 6-8, reprinted in 1984 U.S. CODE CONG. \& ADMIN. NEWS 3182, 3189-90.

6. Williamson v. United States, 184 F.2d 280, 282-83 (2d Cir. 1950).

7. See Note, When Preventive Detention is (Still) Unconstitutional: The Invalidity of the Presumption in the 1984 Federal Bail Statute, 61 S. CAL. L. Rev. 1091 (1988).

8. 18 U.S.C. $\S 3142(\mathrm{~g})(1988)$.

9. E.g., United States v. Portes, 786 F.2d 758, 762 (7th Cir. 1986); United States v. Delker, 757 F.2d 1390, 1399 (3d Cir. 1985); United States v. Hurtado, 779 F.2d 1467, 1472 (11th Cir. 1985); United States v. Maull, 773 F.2d 1479, 1487 (8th Cir. 1985); United States v. Montamedi, 767 F.2d 1403, 1406 (9th Cir. 1985); United States v. Hazime, 762 F.2d 34, 37 (6th Cir. 1985).

10. E.g., United States v. Fortna, 769 F.2d 243, 250 (5th Cir. 1985); United States v. Chimurenga, 760 F.2d 400, 405 (2d Cir. 1985); United States v. Williams, 753 F.2d 329, 333 (4th 
which standard better comports with the legislative intent of Congress and properly weighs the rights of the defendant. Pretrial detention is a reality in our criminal justice system; therefore courts must develop a means of carefully monitoring it to ensure that it is properly administered. A uniform standard of review should guarantee defendants fair and consistent review, should achieve congressionally mandated objectives, and will provide guidance to judicial officers making release or detention determinations.

This Note examines the review standards currently adopted by the courts, ${ }^{11}$ proposes a framework for determining an appropriate standard, and recommends adoption of a two-pronged standard of review. Section I of this Note summarizes the salient pretrial provisions of the BRA. Section II traces the conflicting standards of review adopted by the circuits. An analysis of important factors to consider in determining a proper review standard appears in section III. Finally, section IV explores the institutional functions of trial and appellate courts and concludes by recommending the adoption of a two-pronged standard of review. This standard provides for a process-oriented review of district courts' fact-finding inquiries coupled with an independent evaluation of district courts' legal determinations. A truly independent appellate review will ensure that courts can safeguard the fundamental rights endangered by pretrial detention.

\section{BACKgROUND OF THE 1984 BaIl REForm Act}

\section{A. Overview of the BRA and Implications of United States v. Salerno}

The BRA comprises the first title of the Comprehensive Crime Control Act of 1984. ${ }^{12}$ This Act repealed certain sections of the 1966 Bail Reform $\mathrm{Act}^{13}$ and established standards and procedures governing the release and detention of defendants in Federal criminal cases. Congress implemented the 1984 bail provision changes in large part to "address the alarming problem of crimes committed by persons on release."14

Cir. 1985); United States v. Jessup, 757 F.2d 378, 387 (1st Cir. 1985).

11. This Note will not address review standards of bail pending appeal. Post-conviction bail standards are more stringent than pretrial standards because the presumption of the defendant's innocence disappears after conviction. See S. REP., supra note 4, at 3, reprinted in 1984 U.S. CodE ConG. \& ADMIN. NEws 3182, 3186-3187, 3209 (comparison of pre- and post-conviction bail).

12. Pub. L. No. $98-473,98$ Stat. 1837 (codified as amended in scattered sections of 18 U.S.C. (1988)).

13. Pub. L. No. $89-465, \S 3(a), 80$ Stat. 214 (1966) (current version at 18 U.S.C. $\$ \S 3141-3151$ (1988)).

14. According to a study discussed in the legislative history, one out of every six defendants released pending trial was re-arrested, and one-third of these defendants were arrested more than once. S. REP., supra note 4, at 6, reprinted in 1984 U.S. CODE CONG. \& ADMIN. News 3182, 3189. 


\section{Section 3142: Release or Detention Pending Trial}

The 1966 Bail Act authorized courts to incarcerate defendants thought likely to flee before trial, but allowed courts to consider a defendant's future dangerousness only in pretrial release decisions for capital offenses. ${ }^{16}$ In contrast, the BRA enables a judicial officer to deny bail to anyone adjudged to pose a risk to community safety. ${ }^{16}$ Although the Act favors conditional release, ${ }^{17}$ subsection 3142 (e) specifically requires that if "the judicial officer finds that no condition or combination of conditions will reasonably assure the appearance of the person as required and the safety of any other person and the community, such judicial officer shall order the detention of the person before trial."18 However, before the judicial officer may impose pretrial detention, she must convene a "detention hearing"19 to determine whether sufficient conditions exist to create the rebuttable presumption of preventive detention. ${ }^{20}$

Subsection 3142(f) establishes the procedures for the detention hearing and grants the defendant specific rights. ${ }^{21}$ Although subsection (f) creates presumptions that actually favor imposing pretrial detention in a limited class of cases, ${ }^{22}$ the government must proffer "clear and convincing" ${ }^{23}$ evidence showing that no condition of release will reasonably assure the safety of the community. Thus, pretrial detention is to be a last resort, imposed only under certain prescribed conditions. ${ }^{24}$

Subsection 3142(g) enunciates specific factors the judicial officer must consider in making her determination. If the judicial officer orders detention, subsection (i) requires her to provide detailed findings of fact and a written statement supporting the detention order. Congress intended these statements to create a well-documented record for the appellate court to review.

15. Bail Reform Act of 1966 , Pub. L. No. $89-465, \S 3($ a), 80 Stat. 214 (current version at 18 U.S.C. $\$ \$ 3141-3150$ (1988)); see also Lay \& De La Hunt, supra note 2, at 936-37 (comparing 1984 BRA to 1966 Bail Act).

16. Preventive detention is deemed presumptively correct if the defendant is charged with specified offenses identified in the BRA. 18 U.S.C. $\$ 3142(\mathrm{e})$ (1988) (outlining conditions creating rebuttable presumption of detention).

17. Section 3142(c) provides a detailed list of possible conditions of release and section 3142(d) details grounds for temporary detention.

18. 18 U.S.C. $\$ 3142(\mathrm{c})$ (1988).

19. Id. $\S 3142(\mathrm{f})(1988)$.

20. Section $3142(f)$ also provides an impressive array of procedural rights. See infra notes $46-50$ and accompanying text.

21. See infra notes $46-50$ and accompanying text.

22. 18 U.S.C. $\$ 3142$ (c) (1988).

23. Id. § 3142(f) (1988).

24. See United States v. Orta, 760 F.2d 887, 890 (8th Cir. 1985) (holding that BRA continues to favor release over detention); see also S. REP., supra note 4, at 7, reprinted in 1984 U.S. CoDE CoNG. \& ADMIN. NEwS 3182, 3189 (setting forth conditional release as preferable to detention). 


\section{Section 3145: Review of Release or Detention Orders}

Section 3145 addresses the review and appeal of release or detention orders. When a magistrate conducts the initial detention hearing, the district court, as the court of original jurisdiction, provides the first forum for appeal. ${ }^{25}$ Unlike the 1966 Bail Act, however, which required the petitioner to seek a second review from the initial trial court, subsection 3145 (c) permits an expedited appeal from a final district court order. ${ }^{28}$

An additional change concerns the appealability of release orders. Under the 1966 Bail Act, defendants possessed the exclusive right to appeal a detention order. ${ }^{27}$ The government had no right to appeal the release of the defendant prior to trial. Subsection 3145(a), however, grants the government an equal opportunity to seek appellate review of a release order. ${ }^{28}$ These modifications represent a substantial change from the prior bail law.

\section{The Salerno Decision and Pretrial Detention}

In United States v. Salerno ${ }^{29}$ the Supreme Court upheld the constitutionality of the preventive detention sections of the BRA. Rejecting constitutional challenges presented by counsel, the Court held that while "[i]n our society liberty is the norm, and detention prior to trial ... is the carefully limited exception,"30 preventive detention violates neither the substantive nor procedural due process mandate of the Fifth Amendment, nor the protections from excessive bail embodied in the Eighth Amendment. $^{31}$ The Court reasoned that preventive detention was not a violation of substantive due process because Congress did not intend pretrial detention to be a form of punishment; rather, it found that preventive detention was simply a regulatory tool adopted to achieve a compelling state interest. $^{32}$ The Court also dismissed procedural due process challenges to the BRA. In light of the detailed procedural safeguards provided in the Act-including expedited appellate review of detention orders ${ }^{33}$ - the Court did not find a violation of procedural due process requirements. ${ }^{34}$

The majority concluded its opinion with an extensive discussion of the history of bail, finding that the Eighth Amendment posited no absolute

25. 18 U.S.C. $\S 3145(a)$, (b) (1988).

26. Pursuant to 28 U.S.C. $\S 1291$ (1982) and 18 U.S.C. $\S 3731$ (1988) (providing for appeal following final district court decision).

27. Bail Reform Act of 1966, Pub. L. No. 89-465, $\S 3$ (a), 80 Stat. 214 (current version at 18 U.S.C. $\S \S 3141-3150$ (1988)).

28. See S. REP., supra note 4, at 29-30, reprinted in 1984 U.S. Code CoNG. \& ADMiN. NEwS $3182,3212-3213$ (discussing government appeals).

29. 481 U.S. 739 (1987).

30. Id. at $754-55$.

31. Id. at $746-52$.

32. Id. at $746-47$.

33. Id. at $742-43$.

34. Id. at 755 (special emphasis placed on adversarial process). 
right to bail. ${ }^{35}$ The Court indicated that Congress could choose to deny bail altogether, as it had in capital cases. It held that bail was, in effect, a statutorily prescribed right because Eighth Amendment protections apply solely in cases where Congress authorized bail. ${ }^{36}$ In those cases, courts could consider bail excessive only when viewed in relation to the interests being pursued. Because of the government's admitted interest in preventing crimes committed by persons released on bail, the Court deemed the need for pretrial detention to outweigh the individual defendant's liberty interest. ${ }^{37}$ Thus, the Court deferred to Congress in holding that pretrial detention constitutes a legitimate means of preventing crimes committed by persons who might otherwise be released on bail. ${ }^{38}$

\section{B. The Process of Review}

\section{The Role of the Magistrate}

The district court remains the court of original jurisdiction for pretrial bail determinations, but the Federal Magistrates Act empowers a magistrate to "issue orders pursuant to section $3142 \ldots$. concerning release or detention" of defendants prior to trial. ${ }^{30}$ Thus, a magistrate will often conduct the detention hearing and make the initial release or detention decision. ${ }^{40}$

In practice, the defendant makes an initial appearance before the magistrate shortly after arrest. ${ }^{\mathbf{1}}$ During the course of this appearance, the Act authorizes the magistrate to hold a detention hearing. ${ }^{22}$ As a routine matter, however, magistrates grant short continuances, ${ }^{43}$ thereby giving the parties time to prepare for the actual detention hearing. ${ }^{44}$

During the detention hearing itself, the BRA entitles the defendant to be represented by counsel, ${ }^{45}$ present witnesses, ${ }^{46}$ testify in his own be-

35. Id. at $752-53$.

36. Id. at 752-55. The Court indicated that it would not reach the larger issue of whether the

Eighth Amendment provided any limitations upon Congress. Id. at 752.

37. Id. at $748-750$.

38. Id. at $742-45$.

39. 28 U.S.C. $\$ 636(a)(2)$ (1988). Section 3141(a) of title 18 authorizes any judicial officer who can order an arrest to conduct the hearing. Thus, these "judicial officers" can include Justices or judges of the United States, magistrates, and other court-appointed officials, and a variety of state court judges.

40. This determination is subject to appellate review. 18 U.S.C $\S 3145$ (1988).

41. The initial appearance is governed by FED. R. CRIM. P. 5.

42. See Weinberg, Federal Bail and Detention Handbook, C1-1181, P.L.J. 3-2 (1988).

43. Id.

44. A recent government study found that five days constituted the average pre-hearing preparation time. In view of the liberty interest at stake in such a magisterial determination, the amount of time allotted for pre-hearing preparation seems inadequate. U.S. GEN. Accounting OfFICE, REport to the Chairman, Subcomm. on Courts, Civil Liberties, and the Administration of Justice, house Comm. on the Judiciary, Criminal Bail: How Bail Reform Is Working in Selected District Courts, GAO B-227612, at 7-15 (GAO/GGD 88-6 Bail Reform) (Oct. 1987) [hereinafter GAO REPORT].

45. 18 U.S.C. $\S 3142(f)(1988)$. 
half, ${ }^{47}$ cross-examine government witnesses who appear and testify, ${ }^{48}$ and present additional evidence by proffer, hearsay, or other means. ${ }^{48}$ In short, the magistrate must conduct a thorough adversarial proceeding before ordering detention.

In making the release or detention determination, the magistrate must evaluate a number of statutorily prescribed factors ${ }^{50}$-including a host of "offense and offender characteristics." The magistrate enjoys considerable discretion in determining whether the combination of these factors is sufficient to invoke the preventive detention order. Thus, the magistrate performs a significant role in that she must determine, based upon "clear and convincing" evidence presented at the detention hearing, whether to release or detain the defendant-and if she decides to release him, under what conditions that release should be granted..$^{52}$ Unfortunately, early evidence suggests that the hearings are woefully inadequate for evaluating the necessity of detention-not that the hearing as established under the BRA is inadequate in principle; rather, that the statutorily prescribed procedures are seldom followed closely in practice. ${ }^{58}$ This circumstance is not surprising because the BRA empowers magistrates to make complex legal judgments affecting important constitutional rights even though most magistrates are not trained lawyers. ${ }^{54}$

46. Id. The Third Circuit, however, has held that the defendant cannot subpoena witnesses, which may make this an empty right. United States v. Delker, 757 F.2d 1390, 1395 (3d Cir. 1985).

47. 18 U.S.C. $\S 3142$ (f) (Supp. V 1987). This entitlement may present problems of protecting defendants' Fifth Amendment rights on the merits of the charges at trial. See United States v. Shakur, 817 F.2d 189, 193 (2d Cir. 1987) (court may prohibit cross examination of defendant); United States v. Perry, 788 F.2d 100, 116 (3d Cir.), cert. denied, 479 U.S. 864 (1986) (court can grant "use-fruits" immunity with respect to defendant's testimony).

48. Delker, 757 F.2d at 1398 . The admissibility of hearsay evidence and the ability of the government to preclude cross examination by presenting affidavits rather than the witnesses themselves, however, weakens this right substantially. See United States v. Acevedo-Ramos, 755 F.2d 203 (1st Cir. 1985); United States v. Fortna, 769 F.2d 243, 250-51 (5th Cir. 1985) (hearsay evidence ruled admissible).

49. The rules of evidence applicable in criminal trials do not apply to detention hearings. 18 U.S.C. § 3142(f) (Supp. V 1987); see also United States v. Golding, 742 F.2d 840 (5th Cir. 1984) (evidence otherwise objectionable at trial admissible at pretrial detention hearing).

50. See 18 U.S.C. $\$ 3142(\mathrm{~g})$ (1988).

51. Id.; see S. REP., supra note 4, at 18 , reprinted in 1984 U.S. CODE CONG. \& ADMIN. NEwS 3182,3201 (outlining offense and offender characteristics).

52. However, the magistrate is authorized to order detention only if it is the sole means of achieving the purposes of the Act. See United States v. Berrios-Berrios, 791 F.2d 246, 251 (2d Cir.) (bail should be denied only in rare cases), cert. dismissed, 479 U.S. 978 (1986); United States v. Montamedi, 767 F.2d 1403, 1405 (9th Cir. 1985) (BRA continues to mandate release under least restrictive means); United States v. Orta, 760 F.2d 887, 890 (8th Cir. 1985) (BRA favors release over detention).

53. Indeed, in one preliminary study, the government has estimated that hearings last 10 minutes or less in large districts and from 30 minutes to two hours in less crowded districts, hardly enough time to conduct the thorough hearing mandated by the BRA. GAO REPORT, supra note 44, at 34.

54. See, e.g., L. Silberman, Non-ATtorney Justice in the United States: AN EMPirical. STUDY 24-25, 29 (1979) (estimating number of untrained and part-time magistrates). 


\section{The Role of the District Court}

The BRA authorizes the district court, as the court of original jurisdiction, to hear the initial appeal from the magistrate. ${ }^{55}$ District courts may, at their own discretion, independently review the magistrate's order and conduct any necessary evidentiary hearings or receive additional affidavits. $^{58}$ The district court can change or amend the magisterial order as if it were amending its own order. ${ }^{\text {b7 }}$

The BRA does not, however, specify the scope of review the district court is to apply to a magistrate's determination. At least one circuit requires the district court to grant a full de novo evidentiary hearing when either party requests one, ${ }^{68}$ but most circuits leave this determination to the district court's discretion. ${ }^{5 \theta}$ The district court may, if it so chooses, make an independent evaluation of the magistrate's decision to release or to detain. ${ }^{80}$ Generally, though, the district court proceeds from the presumption that the magistrate's decision is correct; ${ }^{61}$ hence, the district court is unlikely to modify the magisterial order unless it decides to conduct its own evidentiary hearings or it concludes that the magistrate committed clear error in issuing her order.

\section{Circuit Courts and Developing Standards of Appellate REVIEW}

\section{A. Development of the "Clearly Erroneous" Standard}

A minority of the circuits use the "clearly erroneous" standard when reviewing the release or detention orders of district courts. The Fourth

55. 18 U.S.C. $§ 3145$ (1988).

56. This review is conducted only at the district court's discretion. The Second, Third, Fifth, and Eleventh Circuits have held that a district judge who reviews a magistrate's order must provide her own findings to support her decision, but need not conduct a de novo hearing. See United States v. Berrios-Berrios, 791 F.2d at 246; United States v. Wong-Alverez, 784 F.2d 1530, 1535 (11th Cir. 1986) (Wong-Alverez II) (sufficiency of record to review transcript of magistrate's hearing); see also United States v. Gaviria, 828 F.2d 667, 670 (11th Cir. 1987) (de novo hearing not required); United States v. Delker, 757 F.2d 1390, 1390 (3d Cir. 1985) (need for de novo hearing for district court to determine).

57. However, subsections 3145 (a) and (b) limit the review to revocation or amendment of the original order. 18 U.S.C. $\S 3145($ a), (b) (1988).

58. See United States v. Maull, 773 F.2d 1479 (8th Cir. 1985).

59. See cases cited infra note 60 .

60. Although the statute is silent on the standard of review, the five circuits that have addressed this question have uniformly held that the district court should conduct a de novo review of the ultimate determination, although what is entailed in a de novo review is not specified. See United States v. Leon, 766 F.2d 77, 80 (2d Cir. 1985) (district court should "reach its own independent conclusion"); United States v. Delker, 757 F.2d at 1390 (de novo review but within discretion of district judge to conduct evidentiary hearing); United States v. Fortna, 769 F.2d 243, 251 (5th Cir. 1985) (de novo review based upon evidence presented before magistrate and any additional evidence presented before district court); United States v. Maull, 773 F.2d at 1480 (de novo review extends to district court ordering detention even if no such motion presented to magistrate).

61. See Weinberg, supra note 42 , at 3-6. 
Circuit $^{62}$ initially implemented this standard and the Second Circuit ${ }^{83}$ followed suit. The First ${ }^{84}$ and Fifth ${ }^{65}$ Circuits employ a similarly deferential standard in that they require the lower court's findings merely be "supported by the proceedings below." This criterion is tantamount to the "clearly erroneous" standard because it precludes independent review of the lower court's determinations, ${ }^{8 B}$ thereby allowing reversal for only the most egregious errors.

When Congress enacted the BRA, it expressly repealed the appellate review standard for pretrial determinations provided for in the 1966 Bail Act. However, Congress neglected to provide a new standard of review for either pretrial release or detention decisions, ${ }^{67}$ although it clearly did not intend to eliminate appellate review. In fact, the revised provisions of the BRA granted expedited review to final district court orders. ${ }^{68}$

Without guidance from Congress as to the standard of appellate review, it was left to the courts to develop a new standard. The first appellate court to address the issue was the Fourth Circuit in United States v. Williams. $^{69}$ Williams involved an appeal by the government from a district court order granting bail to two individuals indicted for serious federal narcotics violations. In overturning the district court's decision to grant bail, the Fourth Circuit adopted a standard of clear error. ${ }^{70}$ However, the court offered no reasoning for its adoption of this deferential standard. The Second Circuit's decision in United States $v$. Chimurenga ${ }^{71}$ also failed to provide a rationale for adopting a deferential standard. Without further elaboration, the court merely cited Williams to support its holding

62. United States v. Williams, 753 F.2d 329, 333 (4th Cir. 1985).

63. See Williams, 753 F.2d at 333; United States v. Chimurenga, 760 F.2d 400, 405 (2d Cir. 1985). The Second Circuit appeared to rethink its standard in United States v. Jackson, 823 F.2d 4 (2d Cir. 1987), where it held that if the district court did not make "explicit," id. at 6, and "concrete," $i d$. at 5, findings, a more flexible standard of review was warranted, and in United States $v$. Berrios-Berrios, 791 F.2d 246, 251 (2d Cir. 1986), where it held that whether the district court considered any conditions which would assure the defendant's appearance is a mixed question of law and fact subject to a more flexible standard of review. The Second Circuit ultimately retreated from this interpretation in United States v. Shakur, 817 F.2d 189, 195-97 (2d Cir. 1987), which attempted to harmonize the seemingly contradictory decisions and strongly emphasized the "clearly erroneous" standard.

64. United States v. Jessup, 757 F.2d 378, 388 (1st Cir. 1985) (quoting C. WriGhT, Federal Practice and Procedure: Criminal 2d $\$ 722$ (1982)). The First Circuit, however, in United States v. Bayko, 774 F.2d 516, 518-20 (1st Cir. 1985), demands independent review of postconviction appeals denying bail. Oddly enough, the Bayko court relies heavily upon Delker, which involved a pretrial bail appeal.

65. United States v. Fortna, 769 F.2d 243, 250 (5th Cir. 1985).

66. Id.

67. Compare Bail Reform Act of 1966, Pub. L. No. 89-465, § 3(a), 80 Stat. 214 (appellate standard for pretrial bail decisions enacted) with 18 U.S.C. $\$ \S 3141-3150$ (1988) (current version, amended BRA excludes former appellate review standard for pretrial bail decisions).

68. See 18 U.S.C. $\$ 3145$ (1988).

69. 753 F.2d 329 (4th Cir. 1985).

70. Id. at $333 \mathrm{n} .12$.

71. 760 F.2d 400 (2d Cir. 1985). 
that the clearly erroneous standard is applicable. ${ }^{72}$ These circuits appear to be continuing to adhere to the congressionally created (and later abolished) review standard adopted under the 1966 Bail Act.

The First Circuit, in creating its own version of the clearly erroneous standard in United States v. Jessup, ${ }^{78}$ relied upon Wright's Federal Practice and Procedure manual, ${ }^{\text {,4 }}$ which states that "[a]n order concerning release prior to conviction is to be affirmed if it is supported by the proceedings below."7s This statement, however, was lifted directly from a provision of the 1966 Bail Act that Congress repealed when it enacted the BRA. ${ }^{78}$

No court gave a justification for granting deference to the lower courts' determinations until the decision in United States v. Fortna. ${ }^{77}$ In Fortna, the Fifth Circuit affirmed a denial of bond to a defendant charged with importing cocaine. The court in Fortna noted that the Jessup court's standard based on what is "supported by the proceedings below" is "more appropriate to our role as an appellate court and is more in keeping with our precedents." ${ }^{178}$ To support its adoption of this standard, the court made a comparison to its earlier ruling under the 1966 Bail Act in United States v. Golding.79 Golding, a case involving a post-conviction appeal, relied upon United States $v$. Thibodeaux ${ }^{80}$ for establishing its review standard. The Thibodeaux court, although specifically ruling on the scope of review given a magistrate's order by a district court, simply noted that the 1966 Bail Act mandated the scope of review for an appellate court when reviewing the pretrial order of a district court. ${ }^{81}$ Congress expressly repealed this section of the 1966 Bail Act, however; thus it should have no persuasive effect under the BRA. ${ }^{82}$

\section{B. Development of the De Novo Standard}

The de novo, or independent, standard of review was first enunciated by the Third Circuit in United States $v$. Delker ${ }^{33}$ and was subsequently adopted by the Sixth, Seventh, Eighth, Ninth, and Eleventh Circuits. These courts uniformly agreed that the appropriate standard for appellate

\footnotetext{
72. Id. at 405 .

73. 757 F.2d 378, 387-88 (1st Cir. 1985).

74. C. Wright, Federal Practice and Procedure: Criminal 2d $§ 772$ (1982).

75. Id.

76. Id. In the 1989 Supplement to Federal Practice and Procedure, an addendum to note 15 indicates that "[s]ome cases have held that this [1966 review standard] continues to be the rule under the 1984 Act." The circuit split is noted, but no substantive change is made in the text of $\S 772$.

77. 769 F.2d 243 (5th Cir. 1985).

78. Id. at 250 .

79. 742 F.2d 840 (5th Cir. 1984).

80. 663 F.2d 520 (5th Cir. 1981).

81. Id. at 521-22.

82. See supra note 67 and accompanying text.

83. 757 F.2d 1390 (3d Cir. 1985).
} 
review was an independent examination of the lower court's legal conclusions.

Delker involved an appeal by defendants who were ordered detained prior to trial under the Racketeer Influenced and Corrupt Organizations Act. $^{84}$ In determining its scope of review, the Delker court found independent appellate review appropriate because the Senate declared that the procedure for appeals under the BRA was "set forth in Rule 9 of the Federal Rules of Appellate Procedure."85 Several years earlier, the Third Gircuit in United States $v$. Provenzano interpreted this very same language from the legislative history of the 1966 Bail Act as requiring independent review of detention orders. ${ }^{88}$ The Delker court also noted that since Congress had amended the 1966 Bail Act to allow the government to appeal release decisions, an expanded scope of appellate review would best serve the public interest. ${ }^{87}$

With minor modifications, the Sixth, Seventh, Eighth, Ninth, and Eleventh Circuits have adopted this standard. ${ }^{88}$ Although these circuits aligned themselves with the Third Circuit, they noted that the reviewing court should neither hear witnesses nor conduct further evidentiary inquiries. ${ }^{\mathbf{8 9}}$ Each of these courts indicated that it would not disturb purely factual findings of the district court, but would conduct an independent review of the release or detention determination itself. However, none of these circuits demanded that the district court conduct a de novo evidentiary hearing, ${ }^{90}$ nor did they make a uniform attempt to scrutinize the fact-finding process used by the magistrate or district court. They merely sought to ensure that reasons for release or detention were set forth in writing for the purposes of appellate review. These courts never carefully articulated the nature of the independent inquiry they envisioned, nor did they discuss the extent to which they would defer to the factual findings of lower courts. This cursory review of the lower courts' fact-finding process results in a reliance on non-Article III magistrates in making serious constitutional determinations.

84. 18 U.S.C. $§ 1962$ (1988).

85. S. REP., supra note 4, at 29 n.92, reprinted in 1984 U.S. Code ConG. \& ADMIN. NEwS $3182,3212$.

86. 605 F.2d 85 (3d Cir. 1979). Under the 1966 Bail Act, the government was not allowed to appeal a release decision; hence, only decisions for detention required a standard of review. See supra notes 27-28 and accompanying text.

87. 757 F.2d at 1399; see also S. REP., supra note 4, at 30, reprinted in 1984 U.S. CoDE CoNG. \& ADMIN. NewS 3182, 3213.

88. United States v. Hazime, 762 F.2d 34 (6th Cir. 1985); United States v. Portes, 786 F.2d 758 (7th Cir. 1985); United States v. Maull, 773 F.2d 1479 (8th Cir. 1985); United States v. Montamedi, 767 F.2d 1403 (9th Cir. 1985); United States v. Hurtado, 779 F.2d. 1467 (11th Cir. 1985).

89. FED. R. APP. P. 9(a) allows appellants to file additional information before the appellate court, but is silent as to whether additional evidentiary hearings should be conducted.

90. An interesting exception to this rule occurred when an Eighth Circuit judge sitting alone, preliminary to a panel consideration, conducted his own evidentiary hearing in a pretrial detention case. See United States v. Jacob, 767 F.2d 505 (8th Cir. 1985). This is the only available evidence of a circuit court actually conducting an evidentiary hearing. As a rule, such conduct is discouraged. 


\section{Factors Influencing the CReation of a Standard}

No single, precise rule exists to guide an appellate court in choosing a standard with which to review lower court decisions; both precedent and legal tradition, however, recognize several factors appellate courts should consider in determining the appropriate scope of review. ${ }^{\text {91 }}$ The most crucial of these factors is congressional authorization. Congress has the authority to set the scope of appellate review in bail appeals because there is (generally) no constitutional right to seek appellate review in criminal cases. ${ }^{92}$ Hence, courts are obligated to apply review standards enacted by Congress.

In the absence of explicit congressional guidance, courts should also consider policy arguments ${ }^{\mathbf{3}}$ - those factors which depend upon matters of established policy, precedent, and judgment, but are not necessarily binding upon the courts." Policy considerations typically include both the importance of the constitutional questions raised by the appeal ${ }^{95}$ and the scope of review applied in analogous situations.

\section{A. Legislative History}

Though Congress failed to articulate a review standard for appellate courts under the BRA, its intentions can be gleaned from a careful study of the Act's legislative history. The 1966 Bail Act provided that courts should affirm pretrial detention decisions on appeal if they were "supported by the proceedings below."98 Thus, under the 1966 Bail Act, the circuit courts applied a deferential (clearly erroneous) standard in reviewing lower court determinations. The 1966 Bail Act, however, did not allow a judicial officer to order detention based upon a finding of "dangerousness," nor did it contain a presumption in favor of detention for a

91. See, e.g., Calleros, Title VII and Rule 52(a): Standards of Appellate Review in Disparate Treatment Cases-Limiting the Reach of Pullman-Standard v. Swint, 58 Tul. L. REv. 403 (1983) (discussing appropriate factors to consider in determining scope of review); Louis, Allocating Adjudicative Decision-Making Authority Between the Trial and Appellate Levels: A Unified View of the Siope of Review, the JudgelJury Question, and Procedural Discretion, 64 N.C.L. REv. 993 (1986) (discussing factors affecting proper allocation of decision-making authority).

92. See Stack v. Boyle, 342 U.S. 1, 12 (1951) (Jackson, J., concurring); see also Evitts v. Lucey, 469 U.S. 387, 392 (1985) (no absolute right to appeal in criminal cases).

93. See generally Monaghan, Constitutional Fact Review, 85 Colum. L. Rev. 229 (1985) (advocating policy considerations in appellate review).

94. See id. Professor Monaghan argues, for example, that constitutional fact review should be a discretionary function.

95. See, e.g., Bose Corp. v. Consumers Union of United States, Inc., 466 U.S. 485, 496 (1984) (appellate court has obligation independently to review violation of First Amendment rights); see also Monaghan, supra note 93, at 230-40 (arguing that constitutional fact review is appropriate where it is discretionary and where it assesses important policy considerations); Note, The Future of Libel Law and Independent Appellate Review: Making Sense of Bose Corp. v. Consumers Union of United States, Inc., 71 Cornell L. REv. 477 (1986) (noting importance of independent appellate review in protecting First Amendment rights).

96. Pub. L. No. $89-465, \S 3($ a), 80 Stat. 214 (1966) (current version at 18 U.S.C. $\$ \S 3141-3150$ (1988)). 
specified group of offenders. Courts have long recognized detention for risk of flight, included in the 1966 Bail Act, as a legitimate exercise of state power..$^{97}$ Hence, Congress apparently envisioned no need for careful appellate scrutiny of pretrial release or detention orders under the earlier bail act.

Although Congress enacted clear pretrial review standards in the 1966 Bail Act, it failed to provide a standard of review for post-conviction detention decisions pending appeal; this created a void which the Third Circuit attempted to fill in United States $v$. Provenzano ${ }^{88}$ which set forth the review standard eventually adopted by each of the circuits. In Provenzano, the court found the general policy goal that "one convicted of a crime shall be entitled to bail while appealing his conviction"sg called for independent appellate review. Provenzano involved the appeal of defendants convicted of violating Federal racketeering laws. The trial court detained the defendants following conviction; the defendants then filed a motion for an order releasing them on bail during the pendency of their appeal. Although the appellate court denied the motion, it did hold that a reviewing court had an obligation to conduct an independent examination of the trial court's decision. The court noted that while Congress had enacted a clear error standard for the appeal of pretrial determinations, Congress had specifically exempted post-conviction review from this standard. ${ }^{100}$

In the absence of statutory guidance, the court looked to Rule 9 of the Federal Rules of Appellate Procedure. Rule 9(b) requires that after the trial court has reached a decision to release or detain, it must set forth "in writing the reasons for the action taken."101 In addition, the parties may include (for appellate review) "such papers, affidavits, and portions of the record"102 as they consider relevant to their appeal. The court interpreted Rule 9(b) to permit appellate consideration of evidence that may not have been submitted to the trial court. ${ }^{\mathbf{1 0 3}}$ If the parties chose to expand the record on appeal, submitting evidence never reviewed by the trial court, it was difficult to see how an appellate court could adopt any standard but de novo review. Hence, the Provenzano court found it necessary for an appellate court to conduct a de novo review of district court bail determinations. ${ }^{104}$ This review, however, did not include conducting further evidentiary hearings (by the reviewing appellate court). It merely enabled

97. See supra note 3 and accompanying text.

98. 605 F.2d 85 (3d Cir. 1979).

99. Id. at 87 .

100. Id. at $91-92$.

101. FED. R. APP. P. 9(b).

102. Id.

103. Provenzano, 605 F.2d at 93. However, the court did not explain how it would accept additional evidence.

104. Id. at 92 . 
appellate courts to consider additional evidence on appeal and then determine independently whether the facts sustained the release or detention order.

Congress, aware of the Provenzano standard, ${ }^{108}$ expressly repealed the pretrial review provisions of subsection 3147(b) of the 1966 Act in enacting the BRA and made no provision for the standard of appellate review of either pre- or post-trial detention decisions. ${ }^{106}$ Congress simply declared that the appellate procedures mirror those "set forth in Rule 9 of the Federal Rules of Appellate Procedure."107 Although the repeal of the former review standard cannot be taken as positive proof of a course of action, it does imply that Congress relied upon (and generally accepted) the post-conviction review standard established in Provenzano. Had Congress intended a deferential standard of review under the BRA, it would not have needed to repeal the review provision of the 1966 Bail Act. There is nothing in the legislative history to suggest that appellate courts were to apply different standards of review in evaluating pre- or post-conviction bail appeals. ${ }^{108}$ The legislative history suggests that Congress intended a single standard of review to prevail-that formulated by the Provenzano court.

Congress made three further changes in the BRA that also demonstrate the need for appellate courts to take a more active role. Under the 1966 Bail Act, petitioners were required to seek a second review by the court of original jurisdiction, even if that court had made the initial determination to release or detain. ${ }^{109}$ The BRA, however, allows for direct appeal to the circuit court from a final district court order. ${ }^{110}$ It would seem to follow, therefore, that the absence of the second review mandated by the 1966 Act requires appellate courts to take a more active role in conducting their reviews. Furthermore, the 1966 Bail Act confined appellate review to those situations "in which the defendant has been detained or has been ordered released subject to the condition that he return to custody after specified hours."111 Thus, the earlier act did not permit appellate review unless the initial hearing imposed some form of actual detention. The BRA, however, allows a defendant to appeal irrespective of whether he

105. See S. REP., supra note 4, at 28, reprinted in 1984 U.S. Code CoNG. \& AdMIN. NewS $3182,3186$.

106. United States v. Delker, 757 F.2d 1390, 1394 (3d Cir. 1985) notes that the legislative history of the BRA is silent on the standard of review.

107. S. REP., supra note 4, at 29-30 \& n.92, reprinted in 1984 U.S. Code Cong. \& ADMIN. NEws 3182, 3212.

108. Given the fact that Congress left the appellate process intact (indeed, expanded it by providing the government a right of appeal), there is also nothing to suggest that Congress intended a return to the pre-1966 Bail Act standard (habeas corpus review).

109. Compare Pub. L. No. 89-465, § 3(a), 80 Stat. 214 (1966) with 18 U.S.C. $\S \S 3141-3150$ (1988).

110. See supra notes $25-28$ and accompanying text.

111. S. REP., supra note 4, at 29, reprinted in 1984 U.S. Code Cong. \& AdMIN. News 3182, 3212. 
was detained because of an inability to meet the prescribed conditions. ${ }^{112}$ With the elimination of these restrictions on the appellate process, Congress seemed eager to invite increased appellate scrutiny of all conditions of release. A third difference in the BRA is that it empowers the government to appeal a release order, an action specifically omitted in the 1966 Bail Act. ${ }^{113}$ This provision enables appellate courts to expand their role in the release decision. Taken together, these modifications foresee an expanded role for appellate review. ${ }^{114}$

\section{B. Constitutional Rights Implicated Under the BRA}

Appellate courts often conduct independent review of lower court decisions when a constitutional right is at stake. ${ }^{115}$ In a case denying bail, an incorrect determination has a chilling effect on personal liberty, thus warranting a strict, encompassing standard of review.

\section{Eighth Amendment Concerns}

The Supreme Court in Salerno declared that the preventive detention sections of the BRA did not violate the Eighth Amendment. ${ }^{116}$ The Court concluded that the Eighth Amendment provides a check primarily against the judiciary, ${ }^{117}$ preventing courts from setting unreasonable bail for otherwise bailable offenses. Congress, however, was found free to create or abolish bailable offenses as benefitted the government's interest. ${ }^{118}$

Traditionally, however, Federal law has been careful to provide bail to all those arrested for non-capital offenses. ${ }^{119}$ Congress permitted courts to deny bail only in exceptional circumstances. ${ }^{120}$ Thus, Congress granted a general right to bail ${ }^{121}$-it did not create special categories where bail was

112. See 18 U.S.C. $\S 3145$ (1988).

113. See supra notes $27-28$ and accompanying text.

114. This development may not necessarily imply the need for independent review; taken together with the other evidence proffered, however, it adds weight to the proposition that Congress intended independent review.

115. See L. Jaffee, Judicial Control of Administrative Action 624-53 (1965); Strong, The Persistent Doctrine of "Constitutional Fact", 46 N.C.L. REv. 223 (1968); see, e.g., Monaghan, supra note 93, at 335 (constitutional fact review requires independent appellate review); Note, supra note 95 (arguing for necessity of independent appellate review).

116. United States v. Salerno, 481 U.S. 739, 752-55 (1987); see also supra note 31 and accompanying text.

117. 481 U.S. at $752-55$.

118. Id; see also supra note 36 and accompanying text. As previously noted, the Supreme Court has yet to determine what limits the Eighth Amendment would put on Congress in denying defendants bail.

119. Stack v. Boyle, 342 U.S. 1, 4 (1951); see Judiciary Act of 1789, § 33, 1 Stat. 73, 91.

120. Courts thought capital defendants were likely to flee; hence courts routinely denied them bail. See Stack, 342 U.S. at 4 (bail generally permitted except in capital cases). Courts also denied bail to those who had threatened jurors or witnesses with physical violence. See Carbo v. United States, 82 S. Ct. 662, 667-68 (Douglas, Circuit Justice 1962) (denial of bail pending appeal because of threats to witnesses); United States v. Payden, 768 F.2d 487, 491 (2d Cir. 1985) (denial of bail prior to trial because of threats).

121. See Mayer, Constitutionality of Pretrial Detention, 60 Geo. L.J. 1139, 1164-69 (history of 
to be provided; rather, it carefully etched out categories where bail could be denied, such as in capital cases.

Though Congress may be able to craft a class of cases to be excluded from the category of offenses receiving bail, there is nevertheless an inherent difficulty: The BRA merely creates a new exception to the otherwise broadly defined category of cases in which bail is permitted. If a person does not fall within the criteria established by Congress for denying bail, that person has a right to be protected from excessive bail. Thus, if a court fails to follow statutory prescriptions for denying bail, renders an incorrect determination and withholds bail, the court violates the Eighth Amendment because the individual falls out of the "bail excepted" category and is placed within the framework of cases in which bail is allowed. In that instance, a court may not set bail higher than that which is needed to assure the appearance of the defendant at trial. Indeed, in the legislative history of the BRA, Congress made clear it would not tolerate unreasonably high amounts of bail set for the sole purpose of detention. ${ }^{\mathbf{1 2 2}}$ If a judicial officer incorrectly incarcerates an individual without bail, the deprivation clearly exceeds that needed to ensure the defendant's appearance at trial; hence, an Eighth Amendment violation has occurred. Thus, the finding of the judicial officer conducting the bail hearing has a direct bearing upon the individual's constitutional right to be protected from excessive bail.

Appellate courts, then, must look to see that lower courts have exhausted all possible conditions of release before ordering detention. The BRA is emphatic that pretrial detention be a last resort. ${ }^{123}$ Circuit courts need to guarantee that lower courts have carefully considered and rejected all release conditions. If a release condition exists that will ensure the appearance of the defendant at trial and protect community safety, failure to order that release condition would result in an Eighth Amendment violation. To ensure Eighth Amendment protections, appellate courts must be able to make an independent determination as to the correctness of the district court's detention order.

\section{Fifth Amendment Concerns}

Although some circuits apply independent review to the actual detention decision, there is another step in the review process to consider. The Fifth Amendment requires that no one be deprived of liberty without due process of law. ${ }^{124}$ The Supreme Court in Salerno held that the preventive

bail in United States).

122. S. REP., supra note 4, at 5, reprinted in 1984 U.S. Code Cong. \& ADMIN. News. 3182, 3187.

123. See supra notes $23-24$ and accompanying text.

124. Under the BRA the deprivation can be lengthy. While the Speedy Trial Act requires a ninety-day release period for most prisoners, it carves out exceptions for complex cases. 18 U.S.C. $\S$ 
detention sections of the BRA passed Fifth Amendment scrutiny because the determination of whether to deny bail is made by a judicial officer subject to appellate review. ${ }^{125}$ This review follows an adversarial proceeding in which the defendant enjoys most basic trial rights. ${ }^{128}$ The Supreme Court in Salerno and Congress in the BRA's legislative history each stress the importance of the procedural safeguards contained in the BRA. ${ }^{127}$

Unfortunately, recent evidence indicates that detention hearings are often never convened or, if held, fail to meet due process requirements. ${ }^{128}$ Given the emphasis placed upon procedural requirements, it is essential that appellate courts pay special attention to the process used by the magistrate and district court to conduct detention hearings. Magisterial decisions should not receive deferential review because pretrial detention raises important constitutional questions. ${ }^{128}$

The right to bail may not be absolute, but like other rights dependent upon statutory construction or implicit in constitutional values, it is so essential to the preservation of other rights ${ }^{\mathbf{1 3 0}}$ that it may be limited only to further a legitimate state interest. ${ }^{132}$ To deprive a defendant of bail without ensuring adequate due process would be to grant Congress the power to impinge upon a defendant's liberty interest without restraint. In the absence of independent appellate review, the risk of unjust detention is simply too great. ${ }^{\mathbf{1 3 2}}$ Thus, it is necessary to have appellate courts closely

3161(h) (1982). These "complex cases" are often the subjects of preventive detention. See Henderson v. United States, 476 U.S. 321 (1986) (upholding delay of two years between indictment and trial).

125. United States v. Salerno, 481 U.S. $739,742-44$ (1987).

126. Id.

127. Id. at 743-45; S. REP., supra note 4, at 7-8, reprinted in 1984 U.S. CODE CONG. \& ADMIN. NEwS 3182, 3190-91.

128. See supra note 53 and accompanying text.

129. Magistrates, as non-Article III judges, do not normally merit the deference often accorded district court judges. This is especially true in cases of constitutional significance. Indeed, some scholars have argued that in any "arising under" or "Federal question" case, it is not necessarily vital that the Supreme Court have review as long as some Article III court has jurisdiction. Hence, because of the serious constitutional issues involved, the district court, as an Article III court, should be statutorily required to conduct a de novo review of magisterial determinations (including de novo evidentiary hearings). See, e.g., Amar, A Neo-Federalist View of Article III: Separating the Two Tiers of Federal Jurisdiction, 65 B.U.L. REv. 205 (1985) (arguing for necessity of some Federal court to hear particular type of case, but not necessarily Supreme Court).

130. Indeed, the deprivation of personal liberty is disabling; in addition to the stigma attached to incarceration, courts have long recognized that the disruption of family life, the loss of association with others, economic hardships, restrictions on travel, the difficulty in preparing an adequate defense, and the increased likelihood of a forced confession place a severe strain upon the individual. See Moore v. East Cleveland, 431 U.S. 494, 503-05 (1977) (incarceration disrupts family life); Papachristou v. Jacksonville, 405 U.S. 156, 164-65 (1972) (ability to travel and associate with family and friends are important rights); Schilb v. Kuebel, 404 U.S. 357, 365 (1971) (liberty is fundamental interest not to be easily limited); Stack v. Boyle, 342 U.S. 1, 4 (1951) (incarceration impedes defendant's ability to prepare adequate defense).

131. E.g., Dunn v. Blumstein, 405 U.S. 330, 336 (1972) (discussing rights unmentioned in Constitution which preserve other rights).

132. In a review of pretrial bail cases in the Eastern District of New York, the General Accounting Office discovered that $26 \%$ of all individuals incarcerated before trial (as flight and/or danger risks) were detained without the benefit of a detention hearing. The district courts did not correct these blatant violations of due process. GAO REPORT, supra note 44, at 29. 
supervise the detention process in order to provide guidance to lower courts and to enforce due process norms.

\section{Framing a Standard of Review}

An appropriate review standard must take into account the institutional functions of courts. Although the legislative history and the magnitude of the constitutional questions involved argue for de novo review, it is important to determine exactly what the appellate courts should review and how they should conduct that review. The scope of review granted by appellate courts cannot be entirely divorced from that made by the district courts. Indeed, as Article III courts, district courts lay claim to having their decisions respected by reviewing tribunals. Thus, before a standard of review can be constructed, the institutional functions and relative capabilities of the district and circuit courts must be briefly explored.

\section{A. Traditional Institutional Functions of Trial and Appellate Courts}

Appellate courts have, arguably, three essential institutional functions. ${ }^{138}$ First, appellate courts are well-suited to develop and declare legal principles that will apply beyond the case at bar and serve as precedent in future cases. Second, they traditionally provide a "corrective function" to guarantee that lower courts have done justice in a particular case. ${ }^{134} \mathrm{Fi}-$ nally, appellate courts can play a supervisory role, thereby ensuring that proper and consistent procedures have been followed throughout the circuit. ${ }^{185}$

The trial judge generally enjoys no significant advantage over an appellate judge in applying a given legal rule to a set of facts. A three-judge appellate panel may, in fact, be in a better position to make legal determinations because it benefits from the give and take associated with judicial negotiation and is not encumbered by the difficult, time-consuming process of conducting evidentiary hearings. ${ }^{136}$ Hence, appellate judges can devote more time to examining legal questions. ${ }^{\mathbf{1 3 7}}$

The grant of a right to appeal also includes the opportunity to correct significant mistakes made at the trial level. ${ }^{138}$ Constitutional rights depen-

133. See Phillips, The Appellate Review Function: Scope of Review, 47 LAw \& ConTEMP. ProBs. 1 (Spring 1984).

134. It is a basic assumption in the American judicial system that appellate review helps ensure the "correctness" of a decision. See Resnik, Precluding Appeals, 70 CoRnEl.1 L. REv. 603 (1985).

135. See Louis, supra note 91, at 1017.

136. See Stern, Review of Findings of Administrators, Judges and Juries: A Comparative Analysis, 58 HARv. L. REv. 70, 72 (1944).

137. Specifically applied to appellate review under the BRA, the reviewing courts perform an important institutional function when they give substance to statutorily prescribed terms. For example, in predicting "dangerousness," a standard replete with intricate problems, appellate courts can provide a substantive, working definition of the term that can serve as future precedent.

138. See Stack v. Boyle, 342 U.S. 1, 6 (1951) (correcting results of bail proceeding); see also Comm'n on Standards of Judicial admin., Am. Bar Ass'n, Standards Relating to Appel- 
dent upon statutory construction are at special risk when determined by a fact-finder who acts alone and thus without the collective wisdom, experience, and consistency an appellate court can bring to bear on a detention decision. ${ }^{139}$ The Supreme Court relied upon this recognition in deciding Salerno. ${ }^{140}$ The constitutional rights implicated in the pretrial release or detention decision and the complexity of the legal judgments the magistrate must make provide a strong case for independent appellate review of the lower court's determination. ${ }^{141}$ Although appellate review in criminal cases is not constitutionally mandated, ${ }^{142}$ the emphasis placed on review of bail decisions favors allowing appellate courts to fulfill their corrective role.

Trial courts enjoy their greatest advantage over appellate courts in making findings of fact from evidence presented directly at trial. This is especially significant when the factual findings are based upon an evaluation of the credibility of witnesses as they have appeared on the stand before a trial judge. However ill-equipped appellate courts are for conducting evidentiary hearings, they are, nevertheless, well-equipped to scrutinize the fact-finding process itself. This is a traditional function of appellate courts ${ }^{143}$ and one that should apply to appellate review of detention hearings. Appellate courts can ensure that individual district court judges and, in turn, magistrates, have followed proper procedures in conducting hearings, thereby eliminating arbitrary or uncertain application of the BRA's release or detention provisions. Congress in the BRA's legislative history and the Supreme Court in Salerno both place heavy emphasis on the procedural safeguards provided in the BRA; hence, to guarantee fairness, it is incumbent upon appellate courts to ensure that correct procedures are followed throughout the circuit.

\section{B. The Two-Pronged Standard of Appellate Review}

In order to prevent unjust detention and implement congressional policy choices, this Note contends that appellate courts should adopt a twopronged standard of review. ${ }^{144} \mathrm{~A}$ two-pronged standard, incorporating a

LATE CouRTS 20-21 (1977) (noting importance of correcting trial court errors).

139. Monaghan, supra note 93, at 239-45; Calleros, supra note 95, at 409-12; see also Chayes, The Role of the Judge in Public Law Litigation, 89 HARv. L. Rev. 1281 (1976) (suggesting that trial judges, acting alone, exercise substantial power).

140. Indeed, the Supreme Court itself corrected the Second Circuit's decision. United States v. Salerno, 481 U.S. 739, 742-45 (1987), rev'g 794 F.2d 64 (2d Cir 1986).

141. This is especially significant when the district court has not made a de novo review of the magistrate's findings. See, e.g., Crowell v. Benson, 285 U.S. 22 (1932) (discussing appellate review of jurisdictional facts).

142. Stack, 342 U.S. at 6 (although this has broad qualifications).

143. See Calleros, supra note 91 , at $415-20$.

144. While this standard may place additional burdens upon appellate courts, the gravity of the pretrial detention issue makes it incumbent upon the circuits to take care that no citizen's rights are violated. If Congress is truly interested in protecting rights and serving justice, it might seek means other than preventive detention to accomplish these ends. 
process-oriented review with the independent review currently used by select circuits, would both acknowledge the limitations of the appellate courts and ensure that lower courts apply fair and consistent standards. The scope of appellate review should turn on the degree of scrutiny the district court gives the magistrate's initial determination, the written findings supplied by the district court, and any additional evidence the parties present to the appellate court.

\section{The Initial Prong: A Process-Oriented Review}

An independent, process-oriented review by appellate courts will force district courts (and magistrates) to consider all possible alternatives to detention and will protect the rights of the defendant. Upon review of a release or detention order, the reviewing court should take the following steps. First, the court should determine if the district court made a de novo review of the magistrate's hearing. If the district court conducted no such review, the appellate court should remand the appeal to the district court for a de novo determination. Second, because appellate courts are not the proper tribunals for conducting evidentiary hearings, they should determine if the judicial officer followed the procedures mandated in the $\mathrm{BRA}^{145}$ and if the process of conducting the detention hearing comports with due process concerns. ${ }^{146}$ The appellate court should seek to discover whether the trial court followed each of the procedural requirements of the BRA. If the district court conducts de novo evidentiary hearings in accordance with due process requirements, the court of appeals should apply a deferential standard to the district court's historical factfindings. ${ }^{147}$ The inherent danger of unjust detention and the poor efforts made thus far in meeting due process requirements demand that circuits conduct a scrupulous review of pretrial detention procedures.

\section{The Second Prong: An Independent Review of Legal Conclusions}

The ultimate determination of whether to release or detain should always be granted independent review because of the important constitutional questions the BRA raises. Hence, the appellate court should look at the evidence proffered and make an independent assessment of whether the defendant should be released or detained. The appellate court should

145. For example, the BRA forbids an undue length of detention or unreasonable conditions of release or detention. 18 U.S.C. $\S 3142$ (1988).

146. The reviewing court must ensure that counsel is granted, an adversarial hearing is provided, cross-examination of witnesses is allowed, etc. See supra notes 44-48 and accompanying text. In short, the reviewing court must police the hearing in order to assure compliance with the salient provisions of the BRA.

147. Even when reviewing additional evidence submitted under FED. R. APP. P. 9, however, the appellate courts can accept historical facts found by the district court and need not reconvene evidentiary hearings. See supra notes 88-90 and accompanying text. 
independently establish whether the facts found by the lower courts, taken together with any additional evidence submitted on appeal, satisfy the statutory standard for detention. The appellate court should ensure that the district court has considered every possible means of release prior to ordering detention. If a release condition exists that will satisfy the demands of the BRA, the appellate court should grant it. An independent review of the district court's decision to release or detain will force district courts to consider alternatives to detention. The reviewing court should not feel bound to the district court's decision and should feel free to amend or modify the release or detention order as if it were the initial decision maker. Thus, the appellate review standard should be an independent review apart from the final order of the district court.

\section{Conclusion}

Appellate courts should carefully review the procedures used in the evidentiary hearings to ensure that due process requirements have been satisfied and to guarantee that alternatives to detention have been considered and rejected before detention is imposed. District courts should be required to conduct de novo review of magisterial orders. If this review occurs, appellate courts should give deference to purely historical findings of fact. In spite of the need to prevent crimes committed by persons released on bail, it remains difficult to reconcile the operation of the preventive detention sections of the BRA with fundamental principles of fairness and justice. Thus, courts of appeals are in a unique position to protect the rights of criminal defendants by conducting an independent review of the trial court's bail determination. Independent appellate review is essential to retain the real force and meaning of the BRA's procedural safeguards-safeguards the Supreme Court held essential to the proper functioning of the BRA. 